\title{
Ownership structure and incentives to invest: dual-structured irrigation cooperatives in Australia
}

\author{
BRADLEY PLUNKETT* \\ Trade and Market Development, Department of Agriculture and Food, Western Australia \\ FABIO R. CHADDAD \\ University of Missouri and Ibmec, São Paulo, Brazil
}

MICHAEL L. COOK

University of Missouri, Columbia, $\mathrm{MO}$

\begin{abstract}
In the past decade, Australia has begun to privatize its irrigation system. Two general models have emerged: a single and a dual ownership structure. This paper examines the trade-offs, costs and benefits, and the attendant efficiencies regarding costs of ownership. In particular, we examine member capital investment incentives and resultant risk-bearing costs related to capital formation. The paper concludes that the dual ownership structure system has significant economic advantages relative to its single-structured counterpart.
\end{abstract}

\section{Introduction}

Australia is highly dependent upon irrigation water for agricultural production and profitability. Although the country's irrigated area is less than $1 \%$ of its total agricultural area, it generates $28 \%$ of total agricultural production and $51 \%$ of total agricultural profit (CSRIO, 2005). Historically, irrigation water supply services schemes have been developed and operated by state governments, often delivering poor financial, resource allocation, and environmental outcomes (Saleth and Dinar, 1999, 2004; Department of Natural Resources and Environment, 2001). As a result, New South Wales (NSW) and Western Australia (WA) transferred their irrigation schemes to local ownership with subsequent improvements in financial and environmental outcomes (Marsden Jacob Associates, 2004; Irrigation Review Steering Committee, 2005).

This paper examines in detail one of the two general ownership structures that have emerged after the privatization of these schemes: the dual ownership governance structure. In NSW, most locally owned, privatized irrigation schemes

*Email: brad.plunkett@agric.wa.gov.au

The authors would like to thank comments and suggestions offered by CEOs Geoff Calder and Murray Smith; lawyer Jenni Mattila, the creator of these innovative structures; and three anonymous referees. 
are formed under federal corporation law but are effectively run and operated as cooperatives since cooperative principles are built into their constitutions and bylaws, including: (i) each member (i.e., customer or user) has a single vote; (ii) the organizations are user-customer focused; and (iii) water entitlements are tied to member ownership (i.e., shareholding) in the firm. These 'corporate' cooperatives are single-structured entities that do not separate asset ownership, maintenance and management of water functions. However, irrigation schemes in WA adopted the dual ownership structure to improve their operating and financial performance. The dual structure separates asset ownership and maintenance from water services and provision management. These entities are structured into a common law mutual and a trading cooperative respectively. The first irrigation scheme to transfer to local ownership and adopt the dual structure was Harvey Water in WA in 1996; in NSW, Coleambally, the last scheme to adopt local ownership, adopted the dual structure in 2000 . $^{1}$

The purpose of this paper is to analyse the organizational efficiency implications, through property rights and ownership costs perspectives, of Harvey and Coleambally's dual governance entities. More specifically, we examine whether these structures are successful in ameliorating the capital formation constraint (also known as the under-investment problem) of traditional, single-structured cooperatives. Theory and empirical evidence suggest that capital formation constraints exist in traditionally structured agricultural cooperatives as a result of high risk-bearing costs (Cook, 1995; Hansmann, 1996; Chaddad et al., 2005). The two dual structure irrigation cooperatives, however, have invested heavily in water-saving technologies, suggesting lower risk-bearing costs.

The paper is organized as follows. The next section reviews the property rights and ownership costs approaches to organizational efficiency, focusing on risk-bearing costs and the associated capital formation problem. Subsequently, Section 3 describes the organizational characteristics of the two dual-structured irrigation cooperatives (Harvey Water in WA and Coleambally in NSW) and also

1 Instead of adopting the single structure model that had characterized the earlier transfers to local ownership in NSW, Harvey irrigators decided to commission research to evaluate an alternative model to better safeguard their fixed asset investment. The other WA irrigation schemes subsequently adopted this dual structure when transferring to local ownership in the late 1990s. Coleambally, unlike other NSW schemes, had the choice of working examples of the single and dual models when it transferred ownership to its irrigators in 2000. Our choice of the two cooperatives under study also highlights the importance of an external secondary market for water. Harvey Water is able to trade its water savings to the Perth metropolitan region and Coleambally is able to on-sell its water savings to users with high fixed use needs (horticulture and livestock) elsewhere in the Murray River system. Coleambally's predominate production mix of annual crops (rice and cotton) is suited to the high variability of flows along the Murray-Darling River system in that these crops can be grown opportunistically. Harvey's stable climate is better suited to a higher proportion of livestock and increasingly horticulture. Crucially, however, we argue that the internal organizational design of the dual structure provides incentives to generate internal investment to capture opportunities arising from external demand for water. 
analyses the economic benefits of (or reasons for) adopting the dual structure and the resultant outcomes of increased investment in water-saving technologies, and subsequent trading of saved water to other users. Section 4 provides an analysis of the dual structure, in particular how it ameliorates the free-rider, horizon, and portfolio problems that are oft-cited causes of financial constraints in traditional cooperatives. In doing so, we attempt to provide a clear connection between the theoretical predictions outlined in Section 2 and the investment outcomes observed in two dual-structured irrigation cooperatives in Australia. Concluding remarks follow.

\section{Property rights, ownership costs and organizational efficiency}

Alternative ownership forms - e.g., investor-owned, patron-owned, or mutual firms - are characterized by the way property rights are assigned to 'owners'. Several authors have argued that aligning residual rights of control with residual claimant rights leads to an efficient use of assets (Grossman and Hart, 1986; Milgrom and Roberts, 1992; Hart, 1995). Residual claimants are those able to receive the net income generated by an asset or bundle of assets such as a firm. Residual control refers to the rights to make any decision concerning an asset's use that are not explicitly specified by law or assigned to another party by contract. They act as the default rules to the use of an asset. By pursuing their own self-interest, residual claimants tend to make efficient residual decisions regarding the use of the firm's resources because they bear the full wealth effects of their decisions.

However, when one party is assigned control of property rights that affect another party's wealth, decision makers do not bear the full wealth effect of their decisions. This implies scope for conflicts of interest. Cook (1995) and Hansmann (1996) provide complementary frameworks for our understanding of these conflicts of interest and the consequent costs of ownership ${ }^{2}$ in patron-owned firms. Cook's (1995) life cycle approach to the evolution of agricultural cooperatives focuses on the conflicts that commonly arise between members pursuing different strategies to maximize their farm wealth within traditionally structured cooperative organizations. Worldwide, variants of the traditional structure are the most common form of cooperation in agriculture. The traditional structure consists of open membership, non-appreciable, nontransferable, and (partly) redeemable shares and capital accumulation via retained earnings.

2 According to Hansmann (1996: 21), 'ownership involves costs. Some of these costs are what might be called governance costs; they include the costs of making collective decisions among the owners, the costs of monitoring managers, and the costs of the poor decisions and excessive managerial discretion ... Another cost is the risk bearing associated with receipt of residual earnings.' 
One major cost of ownership in patron-owned organizations (i.e., cooperatives) is related to risk bearing, i.e. 'the cost of bearing important risks associated with the enterprise, since those risks are often reflected in the firm's residual earnings' (Hansmann, 1996: 44). The higher these risk-bearing costs are, the more difficulty the organization has to raise risk capital from owners (i.e., patrons or members) to fund investment. The capital constraint problem in user-owned organizations - that is, their inability to acquire sufficient risk capital to finance investment projects - is usually explained on the basis of the following arguments: (i) cooperative residual claims are restricted; (ii) cooperative members do not have appropriate incentives to invest; (iii) equity capital acquisition in traditional cooperatives is tied to member patronage (with consequent dependence on internally generated capital); and (iv) cooperative equity capital is not permanent.

The first argument supporting the capital constraint problem is that cooperatives have restricted residual claims (Fama and Jensen, 1983). User (or patron) ownership limits the extent of agent markets for risk bearing and capital provision since only active members may provide the cooperative organization with voting equity capital. As a result, risk capital acquisition in the traditional cooperative firm is limited by the number, the wealth, and the risk-bearing capacity of member patrons. Since modern agriculture is a capital-intensive business and farming returns are positively correlated to cooperative upstream and downstream returns, producer members may be at a disadvantage and thus incur relatively high risk-bearing costs to supply capital (Hansmann, 1996).

Another restriction on cooperative residual claim rights is their lack of alienability. Residual claims to the firm's net cash flows are non-transferable in the traditional cooperative, which prevents the functioning of a secondary market for cooperative shares. Voluntary contractual restrictions on residual claim alienability may not be efficient in organizations where the 'capital value problem' is important, that is when productive activities are supported by large quantities of long-term assets that are difficult to value (Fama and Jensen, 1985). The non-transferability of cooperative residual claims may result in the emergence of portfolio and horizon problems. Since members can neither capture the long-term payoffs of their risky investments in cooperatives due to the horizon problem nor adjust their investment portfolios to match individual risk preferences due to the portfolio problem, they tend to influence cooperative investment decisions and restrict the supply of capital (Jensen and Meckling, 1979; Cook, 1995).

An additional factor affecting the ability of cooperatives to raise capital is that the property rights allocation within the traditional cooperative structure may not provide members with the necessary incentives to invest (Vitaliano, 1983; LeVay, 1983; Cook and Iliopoulos, 2000). Because cooperatives return earnings to members on the basis of patronage (in the form of patronage allocations) instead of dividends, cooperatives generally pay low - and often zero - returns on 
capital, which impacts negatively on investment when member capital provision is not tied to patronage. In addition, residual claims in traditional cooperatives are not appreciable since they are non-transferable, and redeemable only at book value. Consequently, members derive benefits from the cooperative mainly through usage and patronage refunds. The free-rider problem thus emerges, as patrons share in the return on cooperative equity capital whether or not they invest in the cooperative (Knoeber and Baumer, 1983).

Disincentives for direct member investment in traditional cooperatives result in their dependence on internally generated capital and any additional earnings from non-member business to raise permanent equity capital. In particular, traditional cooperatives rely primarily on patronage-based methods for acquiring risk capital, that is retained patronage refunds and per unit capital retains. However, the user-ownership principle may hinder the cooperative's ability to generate earnings, as it strives to maximize returns to members if horizon, portfolio and free-rider problems are allowed to emerge (Staatz, 1987).

As a result of the dependence on internally generated capital, a high proportion of equity capital in a cooperative's balance sheet may be allocated to individual members, representing a claim against the cooperative by present and former members who still have retained patronage refunds in the firm. This claim is redeemable, with the ultimate payments to members being at the discretion of the board of directors. Because redeeming equity is a cash outlay to the cooperative, equity capital may not be permanent if allocated equity is a large proportion of total equity.

As a consequence of the nature of their residual claims, cooperatives may incur relatively high risk-bearing costs and therefore be constrained in acquiring risk capital for investment purposes. That is, the nature of residual claims in cooperatives can be a source of organization inefficiency - i.e., higher ownership costs - relative to competing forms of ownership (Fama and Jensen, 1983; Cook, 1995; Hansmann, 1996). Recent empirical evidence suggests the presence of financial constraints in a sample of US agricultural cooperatives with traditional ownership structure (Chaddad et al., 2005). In the next section, we describe the ownership and organizational characteristics of non-traditional, dual-structured irrigation cooperatives in Australia and examine how they might ameliorate the risk-bearing costs of their traditional counterparts.

\section{The privatization of irrigation schemes: local ownership, self-funded investment and water trading}

Situated $140 \mathrm{~km}$ south of Perth, WA and settled around 100 years ago, the Harvey area's predominant land uses are dairy and beef, with the balance consisting mainly of horticulture (Economic Consulting Service, 2006). Water is sourced from catchments in neighbouring hills and the irrigation scheme area 
is around 112,000 ha, of which about 10,000 ha are currently irrigated from a possible 35,000 ha (State Water Strategy, 2005).

The Coleambally scheme, located $620 \mathrm{~km}$ west of Sydney and $420 \mathrm{~km}$ north of Melbourne, was the last irrigation system developed on the Murray-DarlingMurrumbidgee River systems in the late 1950s. It consists of around 80,000 ha of intensive irrigation (e.g. crops such as rice and chickpeas), 40,000 ha of mixed irrigation, dry-land farms, and 300,000 ha of outfall district stations with grazing and opportunistic irrigation in very wet years. The development of higher value crops was restricted until the 1980s to avoid competitive pressure on other irrigation schemes along the Murray River system.

Not unlike other irrigation schemes in Australia, Harvey Water and Coleambally were originally organized as state-owned enterprises. Problems related to past development approaches guiding the water sector - leading to water overexploitation and over-allocation - and emerging pressures from urban growth and environmental sustainability have led to water institutional reforms in Australia since 1995 (McKay, 2005). One important aspect of recent Australian water institutional reform is privatization of water irrigation schemes. By divesting themselves of service delivery, state governments are better able to impose tighter licensing obligations on to the newly privatized irrigators. A condition of bulk water licences issued to Coleambally, for instance, is the implementation of community developed land and water management plans, which are integrated into the Murrumbidgee Catchment Management Plan. Similarly, Harvey Water's bulk water allocation is tied to regulatory conditions stipulated by the Department of Water and the Economic Regulation Authority in WA.

Tight matching regulatory controls have, in turn, been imposed on individual irrigators as a consequence of their cooperative ownership. For example, Harvey Water's legal right to bulk water is transferred to owners who have an equity entitlement to water via their shareholding in the cooperative. More specifically, members' ownership rights in the cooperative are proportional to their individual water allocation. In keeping with the Council of Australian Government's (COAG) 1994 policy framework, ${ }^{3}$ the introduction of privately owned structures provides a means for separating water ownership entitlements from land titles and consequently for water to be traded internally by members; that is, transferable water entitlement certificates (TWE), outlining the conditions under which water is delivered, are 'stapled' (i.e., tied) to member's shares. Some members have accessed the inherent value of their water entitlements by borrowing against their shares, with the encumbrance registered on the

3 The objective of COAG's framework was to move urban and rural water use towards 'full cost recovery, separation of water access rights from land title, trading of water rights to allow water to move to more efficient uses, and the need for specific provision of water for the environment' (Australian Senate, 2007). 
cooperative registers. The cooperatives are also able to trade their own water entitlements issued for the purpose of conveying water to members' properties if they are able to invest in water-saving technologies to reduce channel leaks, seepage, and water evaporation. However, they cannot sell or encumber water entitlements within the bulk entitlements owned by their members.

\section{Organizational characteristics of the dual structure irrigation cooperatives}

Table 1 exhibits the differences in residual claim characteristics between an investor-owned corporation, a traditional single-structured cooperative, the single-structured irrigation corporation cooperative, and the dual ownership structure adopted by the irrigation schemes under study in this paper. Both irrigation schemes under study were transferred to user-owned organizations formed under respective State cooperative law. The Harvey Water asset mutual known as the South West Irrigation Asset Cooperative (SWIAC) - assumed ownership of irrigation assets upon transfer to local ownership in 1996. On transfer to local ownership, the assets of the Coleambally scheme were transferred to the trading cooperative. The asset mutual - called Coleambally Irrigation Mutual Cooperative Limited (CIMCL) - will assume ownership of all of Coleambally's assets over time, as they are replaced using CIMCL funds. The respective trading cooperatives are the South West Irrigation Management Cooperative Ltd (SWIMCO, trading as Harvey Water) and Coleambally Irrigation Cooperative Ltd (CICL). Figure 1 presents the key design features and main functions of the dual structure adopted by Coleambally and Harvey Water.

Although each set of trading and mutual cooperatives share a common membership, the two entities operate with totally separate independent boards. In the Harvey Water cooperatives (SWIAC and SWIMCO) and in Coleambally's trading cooperative (CICL), shareholdings are in proportion to the amount of water entitlements held by each member; that is, water entitlements - in the form of transferable water entitlement (TWE) certificates - are 'stapled' to members' ownership shares. Stapled securities are created when two or more rights are contractually bound together - in this case, water entitlements and cooperative shares - so that they cannot be sold separately. There are no shares issued to members by Coleambally's mutual (CIMCL) and irrigators are treated strictly as members, not shareholders, as required by NSW law. The annual contributions paid by each member are based on the water entitlements held in CICL access licences; in SWIMCO, they are based on the number of shares held. All shares have a constant, fully paid value of $\$ 1$ each. Each member in the trading cooperatives and mutuals has one vote regardless of the number of shares held.

The trading cooperatives have adopted active membership rules stipulating that shares must be redeemed in less than three years if shareholders do not use 
Table 1. Property rights characteristics of alternative ownership structures

\begin{tabular}{|c|c|c|c|c|}
\hline & Open corporation & Traditional cooperative & $\begin{array}{l}\text { Single-structured } \\
\text { corporations law irrigation } \\
\text { services cooperatives }\end{array}$ & $\begin{array}{l}\text { Dual-structured } \\
\text { irrigation services } \\
\text { cooperatives }\end{array}$ \\
\hline Assignment of residual claims & To investors & To member-patrons & To member-patrons & To member-patrons \\
\hline $\begin{array}{l}\text { Separation of ownership from } \\
\text { other functions }\end{array}$ & Yes & No & No & No \\
\hline Control rights & $\begin{array}{l}\text { Voting rights } \\
\text { proportional to } \\
\text { shareholdings }\end{array}$ & Non-proportional voting rights & $\begin{array}{l}\text { Either limited voting rights } \\
\text { proportional to } \\
\text { shareholdings or } \\
\text { non-proportional voting } \\
\text { rights }\end{array}$ & $\begin{array}{l}\text { Non-proportional } \\
\text { voting rights }\end{array}$ \\
\hline Residual claims and patronage & Not tied & Tied, but not proportional & $\begin{array}{l}\text { Either not tied or tied and } \\
\text { proportional }\end{array}$ & Tied and proportional \\
\hline Transferability of residual claims & Yes & No & Either Yes or No & Yes \\
\hline Horizon of residual claims & Unlimited & As long as patron & $\begin{array}{l}\text { Either unlimited or as long } \\
\text { as patron }\end{array}$ & Unlimited \\
\hline Redeemability of residual claims & No & At the discretion of the Board & $\begin{array}{l}\text { At the discretion of the } \\
\text { Board }\end{array}$ & Effectively No \\
\hline $\begin{array}{l}\text { Separation of long-term } \\
\text { ownership / management of } \\
\text { fixed assets from short-term } \\
\text { management / trading } \\
\text { functions }\end{array}$ & No & No & No & Yes \\
\hline
\end{tabular}

Source: Adapted from Chaddad and Cook (2004). 
Figure 1. Organizational design characteristics of dual-structured irrigation cooperatives

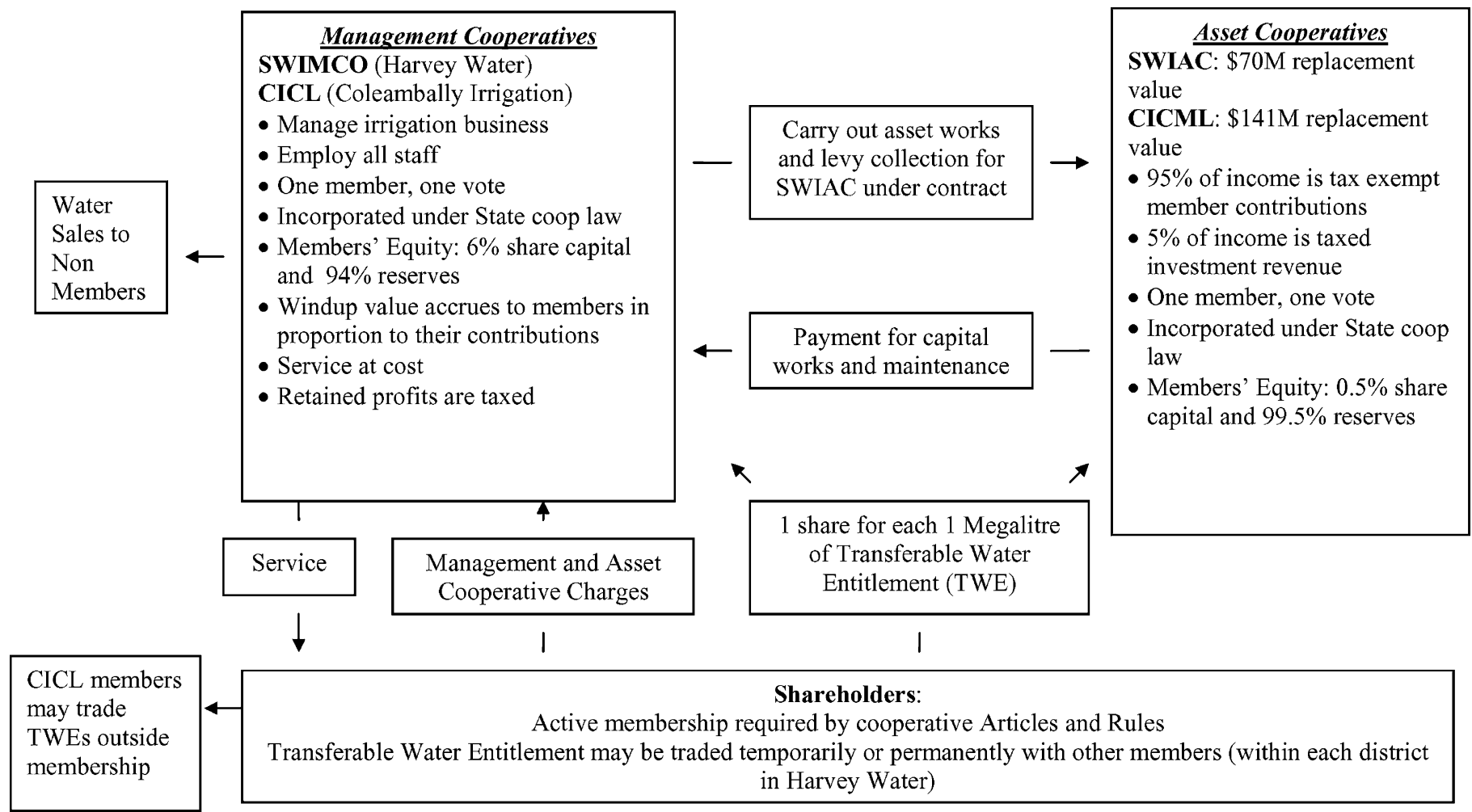


entitlements to trade. In addition, shares must be redeemed at par value and water entitlements at market value. The water could be retained by the cooperative or sold. However, shares and water entitlements have not been redeemed because active secondary markets exist for water entitlements and consequently the shares 'stapled' to them.

Contributions from members received by mutuals form a common fund to provide goods and services in pursuit of a common objective and are not treated as assessable income; they are treated as mutual receipts. Any funds that are not member contributions, but income from those funds, are taxable. This long-enshrined common law principle is based on the proposition that a taxpayer cannot derive income from itself. Specifically, if members contribute to a common fund created and controlled by them for a common purpose, and those contributing members are essentially the same as those who participate in the fund, then member contributions and receipts from member dealings are not taxable income. This mutuality principle has formed the basis of many cooperative insurance entities and mutual banking organizations, such as credit unions and building societies.

Equity capital in the dual-structured irrigation cooperatives is permanent because trading of shares provides liquidity for members' equity without creating the need for cash outlays in the form of equity redemption. In addition, most equity capital in the irrigation cooperatives is not allocated to individual member accounts. The value of unallocated equity in CIMCL is $100 \%$ of total equity, while it is nearly $99 \%$ in SWIAC as shares represent only $1 \%$ of total equity. The proportion of unallocated equity in the trading cooperatives (CICL and SWIMCO) is above $90 \%$.

Investments in water efficient infrastructure result in one or more of the following benefits to members: lower operating costs for the trading cooperatives; increases in water availability to members for additional farm use or sale in temporary (i.e. rent or lease) markets; reduction in associated water costs at farm level; or the adoption of new, farm-level technology.

Table 1 indicates that the key difference between the property rights structure of the single-structured and dual-structured irrigation cooperative is the separation of long-term management and ownership of fixed assets from short-term management and trading functions; that is, while the single-structured irrigation services cooperative may be structured to deal with the afore discussed property rights difficulties associated with the traditional open cooperative structure, it lacks the additional efficiency gained from the protection of its core assets afforded by the dual structure.

\section{Reasons for adopting the dual structure}

Irrigation cooperatives typically make provisions for asset renewal. For instance, the 2007 annual report of Murray Irrigation Ltd - a 'corporate' single structure cooperative - indicates that it charges for asset renewal and maintenance and that 
its asset renewal reserve grew by $13 \%$ in that year. At issue is whether the dual structure offers additional incentives encouraging a pattern of higher investment over time. The organizational innovation (i.e. the dual structure) emerged in WA and was subsequently adopted by Coleambally for three main reasons as follows.

\section{Dual structure advantage one}

First, and most importantly, they judged the dual structure as a better means of lowering the risk to their irrigation assets, as a balance is struck between the conflicting objectives of long-term asset renewal and short-term financial pressure. Under government ownership and control, irrigation entities had experienced constant pressure from irrigators to charge inadequate water prices and not to retain capital to build investment funds because irrigators were suspicious that retained capital would be diverted to government-consolidated revenue. While private ownership improved incentives to lift water prices and retain capital - as the irrigators themselves now owned the assets - pressures to lower prices, reduce expenditures on asset maintenance and new capital items, and eat into accumulated reserves remain, particularly during periods of financial stress for irrigators such as a period of extended drought. At issue is whether the dual structure better insulates the business from these pressures.

The better balance between the conflicting objectives of long-term asset renewal and short-term financial pressure results from separating the operating boards of the asset mutual and the trading cooperative, which allows them to focus on each of these objectives respectively. The entities, however, retain common memberships. The mutual cooperatives' sole obligation to members is to ensure long-term infrastructure provision. As non-trading, non-borrowing asset mutual entities, they operate on the basis of minimum financial risk. This is opposed to a shorter horizon of trading conditions, which in turn are determined by the need for operational efficiency, interaction with government entities, and, most importantly, shareholder pressure for the lowest possible price structure. As a result, raising capital to maintain asset renewal and to fund additional capital expenditures could be problematic in the trading cooperative, particularly during times of financial stress. Further, the existing asset renewal and maintenance investment pool is not put at risk by immediate financial pressures that may periodically arise for the trading cooperative from shareholders to minimize water prices charged to members.

The steady provisioning of sinking funds ensures that capital is available to deal with the lumpy nature of irrigation asset investment, which is around 10-20 times normal yearly expenditure every 25 years (Figure 2). This suggests that a very low discount rate is used to generate a return on capital sufficient to justify investment. This low implied rate of return is consistent with the objective of maintaining the value of farm assets, which is historically a common objective of many agricultural cooperatives (Cook and Plunkett, 2006). In other words, risk-bearing costs are relatively low in the mutual. 
Figure 2. Coleambally's pattern of irrigation asset replacement expenditures Source: CICL (2006).

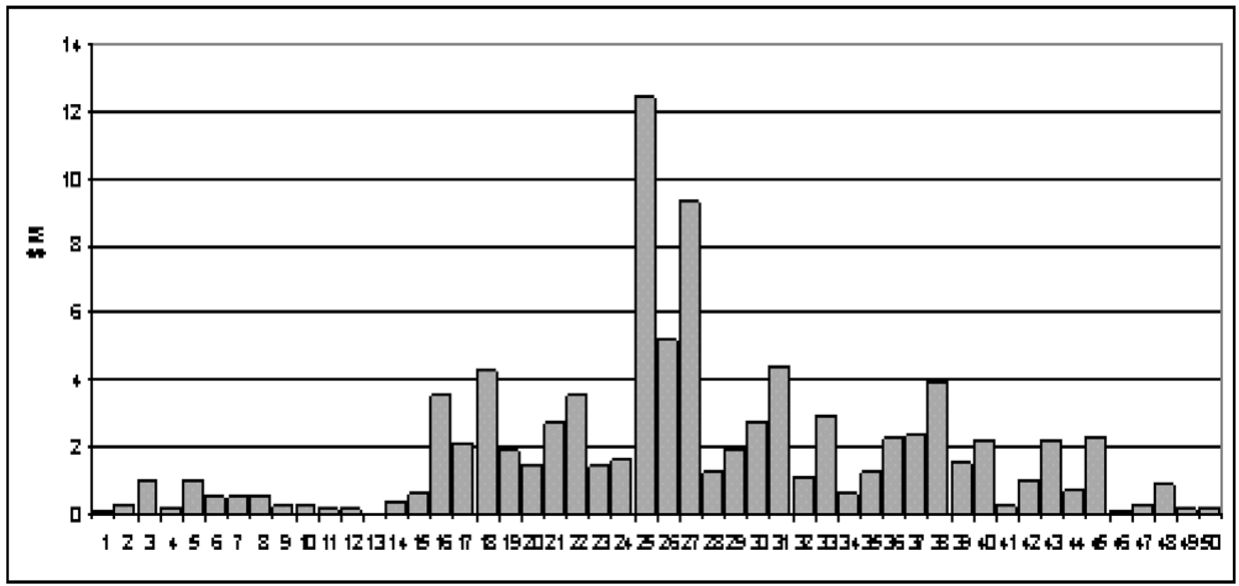

Coleambally mutual's 2005 annual report indicates that it carried no debt and total liabilities were $2 \%$ of total assets. Similarly, Harvey Water's mutual carried no debt and its total liabilities - primarily deferred tax - were $23 \%$ of total assets in 2006. Reducing risk to the irrigation assets means that the return to these assets can be further lowered when considering irrigation investment decisions. Again, this is another indication of relatively low risk-bearing costs to the owners. Indeed the mutuals' objective is to break even over time and also to build funds at a replacement cost rate of depreciation. A mutual with no debt and relatively young assets will build cash reserves for future expenditure relative to a mutual with no debt and older assets requiring more immediate expenditure. Therefore, Coleambally mutual's 2005 return on total investment of $24 \%$ - measured as the ratio EBIT/Shareholder's Equity - should be viewed in context of building reserves for the long-term pattern of investment as illustrated in Figure 2. Additionally, this ratio might be considered inflated because the scheme's irrigation assets are only transferred to the mutual as the assets are replaced.

Harvey Water mutual's return on total investment is $4.6 \%$ as it holds the bulk of the irrigation assets; the trading cooperative holds new assets that are transferred to the mutual as the debt on them is paid. Harvey Water's assets are older than Coleambally's (SWIMCO, 2006). Coleambally's 2004 annual report indicates that $75 \%$ of the mutual's non-current assets - in particular, the sinking fund for future asset replacement - are invested in financial assets that are often characterized as low risk (e.g., balanced and diversified funds) and $25 \%$ is held in a capital growth instrument. These types of investments are reflective of long time horizons. Harvey mutual's financial investments are very low risk - primarily 
deposits yielding 5-6\% p.a. (SWIAC, 2006) - as it requires funds sooner than Coleambally.

\section{Dual structure advantage two}

The second benefit of the dual structure is tax effectiveness. This is because the single entity structures must pay corporate tax of $30 \%$ on profits retained to build their asset renewal funds. Coleambally estimated that, if taxed similarly to 'corporate' cooperative irrigation structures, its tax liabilities would have increased by $\$ 1.5 \mathrm{~m}$ over the first five years of its existence (CIMCL, 2004). Harvey Water mutual's weighted average effective tax rate was 6\% in 2006 and $9 \%$ in 2005 (SWIAC, 2006). It estimated that the possible loss of its mutual status in 2004 would have increased its tax liability by around $\$ 1.1 \mathrm{~m}$.

\section{Dual structure advantage three}

The third benefit is that the dual structure sharpens the transparency between asset management and trading management functions. Each entity has a separate board of directors with clearly demarcated functions. The relationship between the two entities, in which day-to-day asset management is delegated from the mutual to the trading cooperative, is defined by a formal agreement. In Coleambally's case, a periodic Due Diligence Report by the mutual's board on the performance of the trading cooperative's management is carried out. Increased transparency and clearly defined roles for agents with decision control rights suggest that the dual-structured cooperatives might be able to ameliorate collective decision-making and management monitoring costs, which are the other forms of ownership costs (Hansmann, 1996).

In keeping with Harvey and Coleambally mutuals' long-term infrastructure focus, actuarial and engineering reports into the schemes' infrastructure needs are commissioned. Perhaps more importantly, the asset mutual entities do not borrow funds or engage in any activity of significant legal or financial risk. While equity funding avoids the additional cost associated with debt funding, the aim is for each generation to pay for the use of the asset at the time of its use. ${ }^{4}$

The mutuals do not directly employ staff but engage services as needed on a contract basis. They have independent boards of directors, which include external, non-member specialists. In addition to planning asset expenditure, their only other function is to manage members' contributed funds. Income earned on

\footnotetext{
4 Conversely, it should be expected that the trading cooperative will have comparatively few assets and its implied rate of return should be higher. This will be the case for Coleambally's trading cooperative in time as it transfers its assets to the mutual upon renewal; its return on total investment is currently $3.2 \%$. Upon transfer to local ownership, Harvey Water's irrigation assets were placed in its mutual. In 2006, Harvey Water's trading cooperative and mutual had respective total equities of $\$ 8 \mathrm{M}$ and $\$ 41 \mathrm{M}$. Harvey Water trading cooperative's return on total investment was $91 \%$ in 2006, which reflects the first tranche of water transfers to the WA Water Corporation's integrated water supply system in exchange for funding for pressurized piping. Its ratio of total liabilities to total assets in 2006 was $71 \%$, the bulk of which was debt.
} 
the investment of members' funds or on income from mutual assets is taxable (SWIAC, 2005).

The trading cooperatives are licensed to undertake to take management functions. They employ all staff; provide all water delivery and asset management services; provide day-to-day management of the irrigation system, including ensuring water licence compliance; and carry out asset works and other management functions such as levy collection on behalf of the mutuals under contract. Should the trading cooperatives fail, the members could replace them with other service providers. The trading cooperatives make recommendations to the mutuals with respect to the program of works, but it is the mutuals' responsibility to review proposals, obtain independent advice, and determine the ultimate program of works (CIMCL, 2006). The mutuals may also invite other parties to submit proposals to undertake works programs.

\section{Lower risk-bearing costs and increased investment}

Harvey Water has invested a total of $\$ 18 \mathrm{~m}$ of its members' mutual contributions towards its system upgrades since privatization in 1996. In 1999, the cooperative decided to substitute its channel water delivery system to a superior, gravity-fed, and semi-pressurized piped system. By 2001, it had begun replacing channels with piping and demonstrated the efficiency of the new system as it has reduced water delivery losses from $30 \%$ to $2 \%$ in the Waroona district. In 2004, it put a proposal to the State government to trade $17 \mathrm{gl}$ (gigalitres) of water savings in return for funding a greatly augmented expansion of the piping system. Collective selling of water to the WA Water Corporation's integrated water supply system (IWSS) has relieved the cooperative from the need to source additional member funds for the project. The improved delivery made possible by piping has spurred a threefold increase in horticulture output in the area. In addition, it could potentially trade a further $22 \mathrm{gl}$ of water from the Collie system, with investment in treatment and interconnecting piping, without affecting its ability to service irrigation demand. The Collie district is not yet connected to the IWSS.

Coleambally's self-funded $\$ 14.2 \mathrm{~m}$ investment in its 'total channel control' (TCC) system between 2002 and 2006 and the subsequent temporary sale by individual members of more than $40 \mathrm{gl}$ of saved water down the Murray in 2006/07 also suggest that the dual cooperative structure provides investment incentives for members and thus ameliorates risk-bearing costs. Around 27\% of Coleambally's TCC investment was from its legacy funding; 520 was from sale of saved water to members, and the balance was from equity capital reserves. In mid-2006, it permanently traded $3.5 \mathrm{gl}$ of its water savings for $\$ 4.9 \mathrm{~m}$ to the governmentsponsored program known as Water for Rivers. The Waters for Rivers program

5 Funding provided by irrigators to government for future capital works when the schemes were government owned and controlled. Coleambally took its legacy funding as a discounted lump sum upon privatization. 
has the objective of securing water entitlements to ensure minimum flows for environmental purposes. In doing so, Coleambally was able to fund the final stage of its TCC system. Individual members temporarily traded their water savings for up to $\$ 500 / \mathrm{ml}$ (million litres) in $2006 / 07$. Members are able to leverage their largely annual crop production by becoming water providers to livestock and perennial producers elsewhere in the river system in dry years.

Coleambally's members have been able to trade water either on a permanent or temporary basis with external buyers since late 2006. This is in common with other irrigation schemes as stipulated by the National Water Initiative (NWI). Permanent trades are limited to $4 \%$ per year of the total bulk water entitlement until 2014 when unlimited trading will be permitted, as stipulated by the terms of the NWI. No permanent water was externally traded in 2006/07 from Coleambally, which is unsurprising given the small premium paid for it. This premium may rise if a recent report's recommendations (ACCC, 2006) are adopted to unbundle water and delivery rights and introduce progressively reducing the fees irrigator entities may charge when water is permanently traded outside their schemes (i.e., termination fees). Rising permanent water values may result in greater propensity to permanently trade water around the Murray River system.

Harvey Water does not permit members to sell water to external users as it argues that the market power of a dominant buyer (the WA Water Corporation) increases the likelihood that the collective value of the asset would not be attained in negotiations. ${ }^{6}$ Secondly, it argues that the largest water efficiency gains are to be realized from collective investment in further upgrading the irrigation system, which is a necessary condition for the adoption of further on-farm water efficient technology. Indeed, Myer (2005) indicates that upgrading to semi-pressurized piping, as Harvey has done in the Waroona area, can result in a $40 \%$ reduction in annual delivery volumes, as there is incentive for landowners to invest in synergistic on-farm application systems, such as drip irrigation.

Investment in water-saving irrigation technology as a means of re-establishing adequate environmental flows along river systems and maintaining water for irrigated production and urban needs is controversial. Firstly, this is because surface water saved from seepage and channel leaks may be lost to the ground water portion of a river system, which is complicated by the poorly understood interaction between surface and ground water systems. Young and McColl (2003) argue that river system-wide water accounting is required to balance losses to the system from all types of water interception and that water trading should be structured to account for these impacts. This underpins the need for necessary and timely investment into mapping and understanding the physical

6 Indeed, Libecap (2007) suggests that the formation of a single water seller to bargain with the City of Los Angles would have redressed the distributional issues that raised the transaction costs of transferring water from low-value agricultural uses to high-value urban uses in the famous 'China Town' episode of the 1920s. 
dimensions of the river system so that accurate water accounting can occur. The Australian Federal Government's 2007 National Plan for Water Security (the Plan) provides funding to generate such data. Young and McColl (2003) also argue that contracts from government involving funding of water-saving investment should result in the surrender of part, or all, of the water license to environmental flow. The Government's Plan also stipulates that half of water savings resulting from federal investment grants will be directed to environmental flows with the other half retained by irrigators. Obviously, at issue is whether this will be the correct proportion, further underpinning the need for accurately establishing the physical dimensions of river systems. In addition, Grafton et al. (2007) argue that public funds should not be used to pay for investment that irrigators would have provided for themselves. The irrigation projects discussed in this paper have not received grants, but the subsidization of any irrigation project is apparently not in keeping with the 1994 COAG Agreement to move to full cost recovery.

\section{Analysis of the dual structure}

This section examines how the organizational design characteristics adopted in the dual-structured irrigation cooperatives increase incentives for members to invest and reduce their risk-bearing costs. The combination of 'stapling' or linking tradable water entitlements to ownership shares and the active membership provisions in dual-structured irrigation cooperatives helps to limit the emergence of a free-rider problem in capital provision, as capital contributions are proportionally linked to asset use by members. In doing so, 'proportional equivalence' between benefits and costs may be achieved - one of the 'design principles' of long-enduring irrigation institutions (Ostrom, 1993). The introduction of disaggregated (discretionary) pricing would further assist in aligning service costs and pricing and thus further tighten the alignment between residual claimants and residual decision makers.

The trading cooperatives' equity capital is largely permanent given the very high proportion of unallocated (or common pool) reserves to equity. Additionally, internal trading of shares provides liquidity to shareholders without creating the need for capital outlays in the form of equity redemption - the most commonly used method in traditional cooperatives. Further, if water entitlements were to be redeemed, the cooperative would do so at market value and in turn would receive an asset that could be sold. As the tradable water entitlements to which shares are 'stapled' are appreciable, the generic private business problem of exiting members extracting some value from their investment appears to be ameliorated. These features suggest the trading cooperatives are well structured for risky strategies, as increases in the value from water trading (price and available volume) can be captured by members directly when trading internally, indirectly via the cooperative when it trades externally and invests 
in water-saving assets, or directly by members in Coleambally's case - that is, transferability and appreciability of water rights proportionally tied to shares help to ameliorate horizon and portfolio problems.

The unique key feature, however, of separating the business into two structures suggests that fixed irrigation assets are protected from any potential failure that may arise from higher risk activities engaged in by the trading cooperatives and that investments in ongoing maintenance can be better shielded in periods of member financial distress. Further, the contractual relationship between the mutual entities and the trading cooperatives in Coleambally and Harvey Water permits the value created by the tax effective structure to optimize the benefit to the common membership of the dual-structured cooperatives. This organizational innovation apparently further ameliorates organization costs inefficiencies fostered by portfolio, horizon, and free-rider investment constraints. The portfolio constraint is mitigated, as different risk classes of investment decisions are unbundled according to a formal and transparent process that assesses the mutual investment needs via the use of third-party (external) engineering and actuarial services. The horizon constraint is ameliorated because the tax effectiveness of the sinking fund redresses the low returns available from very long lead times inherent in water infrastructure investment. In other words, a very low discount rate must be employed to justify investment with long lead times. The free-rider constraint is further ameliorated because the mutuality induced tax effectiveness also encourages investments in infrastructure with a large public goods component.

In sum, amelioration of free-rider, horizon, and portfolio problems results in lower risk-bearing costs, which suggests organizational efficiency gains in terms of reduced costs of ownership; that is, the organizational design characteristics of the dual-structured irrigation cooperatives suggest that, all other things being equal, these structures should have a higher rate of capital formation than alternative ownership structures to fund irrigation construction and maintenance projects. Perhaps more importantly, the costs of constructing, operating, and maintaining these irrigation systems are roughly proportional to the benefits that irrigators obtain from their cooperatives.

Rising water prices provides a market signal to invest in water-saving technology, which further ameliorates capital formation constraints. However, rising water prices could also lead to an increase in internal conflicts among members as retiring irrigators may view an opportunity to individually sell permanently to higher priced markets as more attractive than selling into lower value markets within the existing bulk allocation structure.

\section{Summary and conclusions}

The purpose of this paper is to examine the property rights attributes and attendant risk-bearing costs of two Australian dual-structured irrigation supply 
entities and compare them with single-level user-owned irrigation systems. The alignment of residual control rights with residual claimant rights is the basis for ameliorating conflicts of interest in capital provision and thus reducing risk-bearing costs. We observe that the trading cooperatives' active member provisions in its articles and its practice of aligning capital to patronage loosely align these residual rights. While this suggests a reasonably efficient organizational design to mobilize financial resources for irrigation system construction, maintenance, and operation, conflicts of interest over the extent of fees paid when permanently trading water within Coleambally may emerge between members preferring different water trading strategies because of the public good nature of irrigation provision. This suggests that some parts of irrigation schemes may become 'unserviceable' if sufficient volumes of water are traded out of the system, which suggests the need for disaggregated water service delivery pricing. Within both structures, scope apparently exists for greater alignment between residual claimant and residual control rights by the introduction of differential pricing in which members are charged prices reflective of actual, rather than pooled costs.

The relationship of the asset mutual entities with their respective trading cooperatives provides a conduit for members to capture the value created in the nondistributing mutual. These structural alignments imply that the dual-structured cooperatives should not face a binding capital formation constraint, and this is supported by their self-funded investment in water-saving technology, which has increased the water volume available to members for irrigation use or sale and permits the adoption of additional investment in water efficiency at the farm level.

\section{References}

Australian Competition and Consumer Commission (ACCC, 2006), 'A Regime for the Calculation and Implementation of Exit, Access and Termination Fees Charged by Irrigation Water Delivery Businesses in the Southern Murray-Darling Basin', available at: http://www.accc.gov.au/content/index.phtml/itemId/771300 [accessed 17 March 2007].

Australian Senate (2007), 'Water Policy in Australia', available at: http://www.aph.gov.au/ SENATE/committee/rrat_ctte/completed_inquiries/2002-04/water/report/c02.htm [accessed 17 March 2007].

Chaddad, F. R. and M. L. Cook (2004), 'Understanding New Cooperative Models: An Ownership-Control Rights Typology', Review of Agricultural Economics, 26(3): 348360.

Chaddad, F. R., M. L. Cook, and T. Heckelei (2005), 'Testing for the Presence of Financial Constraints in US Agricultural Cooperatives: An Investment Behaviour Approach', Journal of Agricultural Economics, 56(3): 385-397.

Coleambally Irrigation Cooperative Limited (CICL) (2006), 'Annual Report'.

Coleambally Irrigation Mutual Cooperative Limited (CIMCL) (2004), 2005 and 2006), 'Annual Reports'.

Coleambally Irrigation Mutual Cooperative Limited (CIMCL) (2006), 'Due Diligence Report'. 
Cook, M. L. (1995), 'The Future of US Agricultural Cooperatives: A Neo-Institutional Approach', American Journal of Agricultural Economics, 77(5): 1153-1159.

Cook, M. L. and C. Iliopoulos (2000), 'Ill-Defined Property Rights in Collective Action: The Case of Agricultural Cooperatives', in C. Menard (ed.), Institutions, Contracts, and Organizations: Perspectives from New Institutional Economics, London: Edward Elgar.

Cook, M. L. and B. Plunkett (2006), 'Collective Entrepreneurship: An Emerging Phenomenon in Producer-Owned Organizations', Journal of Agricultural and Applied Economics, 38(2): 421-428.

Commonwealth Scientific and Industrial Research Organisation (CSIRO, (2005), 'Irrigation in Perspective: Irrigation in the Murray and Murrumbidgee Basins: A Bird's Eye View', Cooperative Research Centre for Irrigation Futures, Commonwealth Scientific and Research Organisation, Canberra, Australia.

Department of Natural Resources and Environment (2001), 'Financial Review of Shepparton and Central Goulburn Irrigation Areas: Goulburn-Murray Water', Melbourne, Australia.

Economic Consulting Service (2006), 'Harvey Water Irrigation Area - Logue Brook Dam Water Value for Irrigation', Perth, WA, available at: http://portal.water.wa.gov. au/portal/page/portal/WaterManagement/Projects/LogueBrook/Content/Value\%20of\% 20LBD\%20Irrigation\%20Water\%202.pdf [accessed 30 March 2006].

Fama, E. F. and M. C. Jensen (1983), 'Agency Problems and Residual Claims', Journal of Law and Economics, 26: 327-349.

Fama, E. F. and M. C. Jensen (1985), 'Organizational Forms and Investment Decisions', Journal of Financial Economics, 14: 101-119.

Grafton, R., J. Bennett, and K. Hussey (2007), 'An Economic Evaluation of the National Plan for Water Security', Dry Water: Policy Brief, Crawford School of Economics and Government, Australian National University.

Grossman, S. J. and O. D. Hart (1986), 'The Costs and Benefits of Ownership: A Theory of Vertical and Lateral Integration', Journal of Political Economy, 94: 691-719.

Hansmann, H. (1996), The Ownership of Enterprise, Cambridge: The Belknap Press of Harvard University Press.

Hart, O.D. (1995), Firms, Contracts and Financial Structure, Oxford: Clarendon.

Irrigation Review Steering Committee (2005), 'State Water Strategy: Irrigation Review Final Report', Perth, WA, available at: http://www.statewaterstrategy.wa.gov.au/index. cfm? event $=$ irrigationReview [accessed 17 March 2007].

Jensen, M. C. and W. H. Meckling (1979), 'Rights and Production Functions: An Application to Labor-Managed Firms and Codetermination', Journal of Business, 52(4): 460-506.

Knoeber, C. R. and D. L. Baumer (1983), 'Understanding Retained Patronage Refunds in Agricultural Cooperatives', American Journal of Agricultural Economics, 65(1): 30-37.

LeVay, C. (1983), 'Agricultural Cooperative Theory: A Review', Agricultural Economics, 34: $1-44$.

Libecap, G., (2007) 'Chinatown Revisited: Owens Valley and Los Angles - Bargaining Costs and Fairness Perceptions of the First Major Water Rights Exchange', Workshop Paper, University of Arizona, available at: http://ele.arizona.edu/papers/ELElibecap330-07.pdf [accessed 18 March 2008].

Marsden Jacob Associates (2004), 'Future Governance of the NSW Abalone Fishery: Alternative Arrangements', NSW Fisheries and the Abalone Development Company, available at: http://www.fisheries.nsw.gov.au/data/assets/pdf_file/4827/AbaloneReport.pdf [accessed 30 March 2006]. 
McKay, J. (2005), 'Water Institutional Reforms in Australia', Water Policy, 7: 35-52.

Milgrom, P. and J. Roberts (1992), Economics, Organization and Management, Englewood Cliffs, NJ: Prentice-Hall.

Myer, W. (2005), 'The Irrigation Industry in the Murray and Murrumbidgee Basins', Technical Report No. 03/05, Cooperative Research Centre for Irrigation Futures, Commonwealth Scientific and Research Organisation, available at: http://www.clw. csiro.au/publications/consultancy/2005/irrigation-industry-murray-CRCIF.pdf [accessed 18 March 2008].

Ostrom, E. (1993), 'Design Principles of Long Enduring Irrigation Institutions', Water Resources Research, 29(7): 1907-1912.

Saleth, R. M. and A. Dinar (1999), 'Water Challenge and Institutional Response: A CrossCountry Perspective', Policy Research Paper 2045, The World Bank, Washington, DC.

Saleth, R. M. and A. Dinar (2004), The Institutional Economics of Water: A Cross-Country Analysis of Institutions and Performance, Cheltenham, UK: Edward Elgar.

Staatz, J. M. (1987), 'The Structural Characteristics of Farmer Cooperatives and Their Behavioural Consequences', in J.S. Royer (ed.), Cooperative Theory: New Approaches, ACS Service Report 18, Washington, DC: USDA, pp. 33-60.

South West Irrigation Asset Cooperative (SWIAC) (2005) and 2006), 'Annual Reports', available at: http://www.harveywater.com.au/annual/Annual.asp [accessed $30 \mathrm{March}$ 2006].

South West Irrigation Management Cooperative (SWIMCO) (2006), 'Annual Report', available at: http://www.harveywater.com.au/annual/Annual.asp [accessed $30 \mathrm{March}$ 2006].

Vitaliano, P. (1983), 'Cooperative Enterprise: An Alternative Conceptual Basis for Analyzing a Complex Institution', American Journal of Agricultural Economics, 65(5): 1078-1083.

Young, M. D. and J. C. McColl (2003), 'Robust Reform: The Case for a New Water Entitlement System for Australia', Australian Economic Review, 36(2): 225-234. 